\section{Pacific Northwest}

National Laboratory

Operated by Battelle for the

U.S. Department of Energy

\title{
Functions and Requirements for West Valley Demonstration Project Tank Lay-Up
}

\author{
M. Elmore \\ C. Henderson*
}

March 15, 2001

*Jacobs Engineering Group, Inc.

Prepared for the U.S. Department of Energy under Contract DE-AC06-76RL01830 


\title{
DISCLAIMER
}

This report was prepared as an account of work sponsored by an agency of the United States Government. Neither the United States Government nor any agency thereof, nor Battelle Memorial Institute, nor any of their employees, makes any warranty, express or implied, or assumes any legal liability or responsibility for the accuracy, completeness, or usefulness of any information, apparatus, product, or process disclosed, or represents that its use would not infringe privately owned rights. Reference herein to any specific commercial product, process, or service by trade name, trademark, manufacturer, or otherwise does not necessarily constitute or imply its endorsement, recommendation, or favoring by the United States Government or any agency thereof, or Battelle Memorial Institute. The views and opinions of authors expressed herein do not necessarily state or reflect those of the United States Government or any agency thereof.

\author{
PACIFIC NORTHWEST NATIONAL LABORATORY \\ operated by \\ BATTELLE \\ for the \\ UNITED STATES DEPARTMENT OF ENERGY \\ under Contract DE-AC06-76RL01830
}

Printed in the United States of America

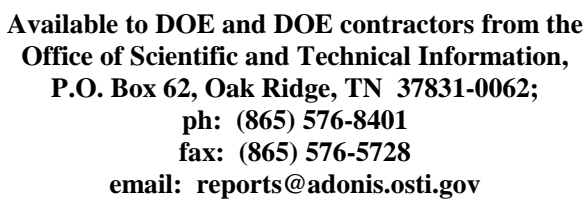

Available to the public from the National Technical Information Service, U.S. Department of Commerce, 5285 Port Royal Rd., Springfield, VA 22161 ph: (800) 553-6847 fax: $(703) 605-6900$

email: orders@ntis.fedworld.gov

online ordering: http://www.ntis.gov/ordering.htm 
PNNL-13898

\section{Functions and Requirements for West Valley Demonstration Project Tank Lay-Up}

March 15, 2001

Prepared for

Tanks Focus Area and

the U.S. Department of Energy

under Contract DE-AC06-76RL01830

Jacobs Engineering Group, Inc., and

Pacific Northwest National Laboratory

Richland, Washington 99352 


\section{FUNCTIONS AND REQUIREMENTS FOR WEST VALLEY DEMONSTRATION PROJECT TANK LAY-UP}

\subsection{INTRODUCTION}

This letter report documents completion of Milestone A.1-1, "Issue Functions and Requirements for WVDP Tank Lay-up," in Technical Task Plan TTP RL30WT21A - "Post-Retrieval and Pre-Closure HLW Tank Lay-Up." This task is a collaborative effort among Pacific Northwest National Laboratory, Jacobs Engineering Group Inc., and West Valley Nuclear Services (WVNS). Because of the site-specific nature of this task, the involvement of WVNS personnel is critical to the success of this task.

The primary objective of the overall task is to develop and evaluate conceptual strategies for preclosure lay-up of the two high-level waste (HLW) storage tanks at the West Valley Demonstration Project (WVDP). Decision criteria will be developed to support selection of a strategy for safe lay-up of the HLW tanks. The lay-up strategies will be evaluated with respect to the decision criteria to provide WVDP with a defensible decision process.

The subtasks identified in the work plan for the overall task are described below. This letter report documents completion of subtasks 1 and 2 that correspond with completion of Milestone A.1-1 in the Technical Task Plan.

Subtask 1 - Review WVDP Information Package. WVDP personnel have conducted preliminary evaluations for tank lay-up. These evaluations have resulted in three fundamental concepts for lay-up: (1) a wet lay-up with a small amount of corrosion-inhibiting liquid in the tanks, (2) dry lay-up, and (3) dry lay-up with several feet of stabilizing material in the bottom of the tank. This subtask involves coordination with WVDP personnel to identify and review available data and information from WVDP on the HLW tanks, environmental conditions, and tank lay-up concepts. Task completed.

Subtask 2 - Develop Tank Lay-Up Functions and Requirements. Functions and requirements will be developed at a level of detail sufficient to support development of the conceptual tank lay-up descriptions. The functions and requirements will identify the objectives of laying up the tanks and the tank lay-up system requirements. The system requirements will identify what is required of the tank lay-up concepts to support the objective of placing the tanks in a safe, stable, and minimum maintenance mode that does not compromise final closure options. Task completed with this letter report.

Subtask 3 - Identify and Evaluate Areas of Technical Concern. In parallel with development of decision criteria, technical areas of concern will be identified and prioritized in consultation with WVDP personnel to ensure that the issues identified correspond to WVDP needs and are relevant to the identified lay-up strategies. A select number of the higher-priority technical concerns will be evaluated by subject matter experts to the extent necessary to factor the concerns into the decision criteria process.

Subtask 4 - Develop Conceptual Description of Tank Lay-Up Options. The three concepts identified for tank lay-up in Subtask 1 will be further developed to the extent necessary to support an evaluation of the concepts against evaluation criteria (performance measures) 
developed under Subtask 2. Any additional concept development will be conducted in conjunction with WVDP personnel to ensure that site-specific issues are addressed.

Combinations of concepts will also be identified for further evaluation if appropriate.

Subtask 5 - Develop Decision Plan. Performance objectives along with specific criteria will be developed to provide a means for evaluating tank lay-up strategies. The objective of the decision criteria process is to provide a technically defensible methodology for evaluating tank lay-up strategies to allow WVDP to move forward with the selection of an approach for implementation. Examples of performance objectives or attributes that will be considered include (1) minimizing monitoring and maintenance costs, (2) meeting environmental regulations for tank closure, (3) protecting worker health and safety, and (4) addressing stakeholder concerns.

\subsection{WEST VALLEY DEMONSTRATION PROJECT BACKGROUND AND OVERVIEW}

\subsection{SITE HISTORY}

The WVDP is located about 30 miles south of Buffalo, New York, on the site of a former commercial spent fuel reprocessing facility which operated from 1966 to 1972. Approximately 640 metric tons of commercial and defense fuels were reprocessed at the site using the plutonium-uranium extraction (PUREX) and the thorium extraction (THOREX) processes. The former site operator, Nuclear Fuel Services, Inc., halted reprocessing operations in 1972 to evaluate the potential for facility expansion. In 1976, Nuclear Fuel Services, Inc. notified New York State that it would withdraw from operating the facility in 1980 when its lease expired. In 1980, the West Valley Demonstration Project Act (WVDPA) was signed, directing the U.S. Department of Energy (DOE) to (1) solidify and develop suitable containers for the site's high-level radioactive waste, (2) transport the solidified waste to a federal repository, and (3) dispose of the low-level radioactive and transuranic wastes created during reprocessing operations. In 1982 DOE took control of the site working closely with the New York State Energy Research and Development Authority. A private company, WVNS, was awarded the operations contract and has been the primary contractor since February 1982. New York State owns both the site and the waste. Under the WVDPA, the DOE is responsible for management of the project and funds $90 \%$ of the cleanup costs while working with New York State Energy Research and Development Authority, which funds the remaining $10 \%$.

Approximately 2,000,000 L (550,000 gal) of neutralized high-level PUREX radioactive waste remained on the site in an underground carbon steel storage tank designated as 8D-2 in 1982. This waste consisted of insoluble hydroxides and other salts that precipitated out of the solution to form a bottom sludge layer, and a liquid top layer rich in sodium nitrate and nitrite (supernate). In addition, approximately 31,000 L (8,000 gal) of acidic THOREX waste remained in an underground stainless steel storage tank designated 8D-4. 


\subsection{HIGH-LEVEL WASTE STORAGE TANKS AND VAULTS}

Underground waste storage tanks 8D-1 and 8D-2 are identical 2,800,000-L (760,000-gal) capacity, carbon steel storage tanks each contained within a secondary containment pan and a concrete vault. Figure 1 is a schematic of the tank and vault configuration. Each tank is $21 \mathrm{~m}$ $(70 \mathrm{ft})$ in diameter and $8.2 \mathrm{~m}(27 \mathrm{ft})$ high with wall thicknesses ranging from 1.3 to $1.7 \mathrm{~cm}(0.5$ to $0.65 \mathrm{in}$.). The bottom floor plates are $1.7 \mathrm{~cm}(0.65 \mathrm{in}$.) thick and the tank roof plates are $1.1 \mathrm{~cm}$ (0.43 in.) thick. These tanks have a complex internal gridwork comprised of a network of wide flange beams supported underneath by vertical plates of varying lengths and widths.

These girders attach to the tank bottom by rods held on with reinforcing disks. Forty-five 22-cm (8.6-in.) diameter pipe columns in each tank connect the beams to the tank top and provide support to the roof. Figure 2 shows the arrangement of the girders and support columns in the tanks. Various air circulators, thermowells, and level/density probes also reside within the tanks. Waste mobilization and removal efforts have been uniquely challenging because of internal tank configuration and the presence of internal structures. The internal structures act to disperse the mobilization pumps' mixing jets, which results in nonuniform cleaning/mixing radii and "dead zones" where the low local velocity causes the solids to fall out of suspension and deposit on tank surfaces.

There is an annular air space of $76 \mathrm{~cm}$ (30 in.) between the tank and vault wall. Each tank rests directly on a 30-cm (12-in.) layer of perlite blocks and the perlite blocks rest on a 7.5-cm (3-in.) layer of pea gravel within the carbon steel secondary containment pan. The secondary

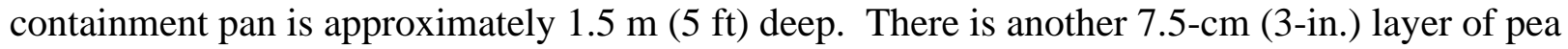
gravel between the pan and the vault floor. The bottom of the vault is $70-\mathrm{cm}(27$ in.) thick except for a thicker ring under the columns that support the vault roof. There are six $1.2-\mathrm{m}$ (4-ft) diameter columns that pass through each tank to support the vault roof. These columns pass through carbon steel tubes constructed of 1-cm (0.4-in.) plate welded to the top plate and floor plate. Figure 3 provides additional detail on the construction of the tanks, including the gravel base below the vaults and the superstructure above the tanks to support the sludge mobilization pumps.

Long-shafted centrifugal mobilization pumps are installed in tanks 8D-1 and 8D-2 to mix settled solids with the liquid supernate. These pumps are each $15 \mathrm{~m}(50 \mathrm{ft})$ in length with a single impeller to draw the slurry up into the pump suction and a strainer device to keep out larger debris. The suction is positioned from 2.5 to $3.8 \mathrm{~cm}$ ( 1 to $1.5 \mathrm{in}$.) from the tank bottom with discharge jets approximately $13 \mathrm{~cm}$ (7 in.) above the tank bottom. Two tangential nozzles are used to discharge liquid from the volute above the suction.

Additionally, one long-shafted vertical turbine transfer pump is installed in tanks 8D-1 and 8D-2. This pump is approximately $12-\mathrm{m}$ (40-ft) long with a radial inlet suction and two concentric strainers about 2.5 to $3.8 \mathrm{~cm}$ ( 1 to $1.5 \mathrm{in}$.) above the tank bottom. The pump is additionally equipped with instrumentation to allow remote operation and performance monitoring and with vibration sensors to monitor pump wear. 
Figure 1. Schematic of Waste Tanks 8D-1 and 8D-2

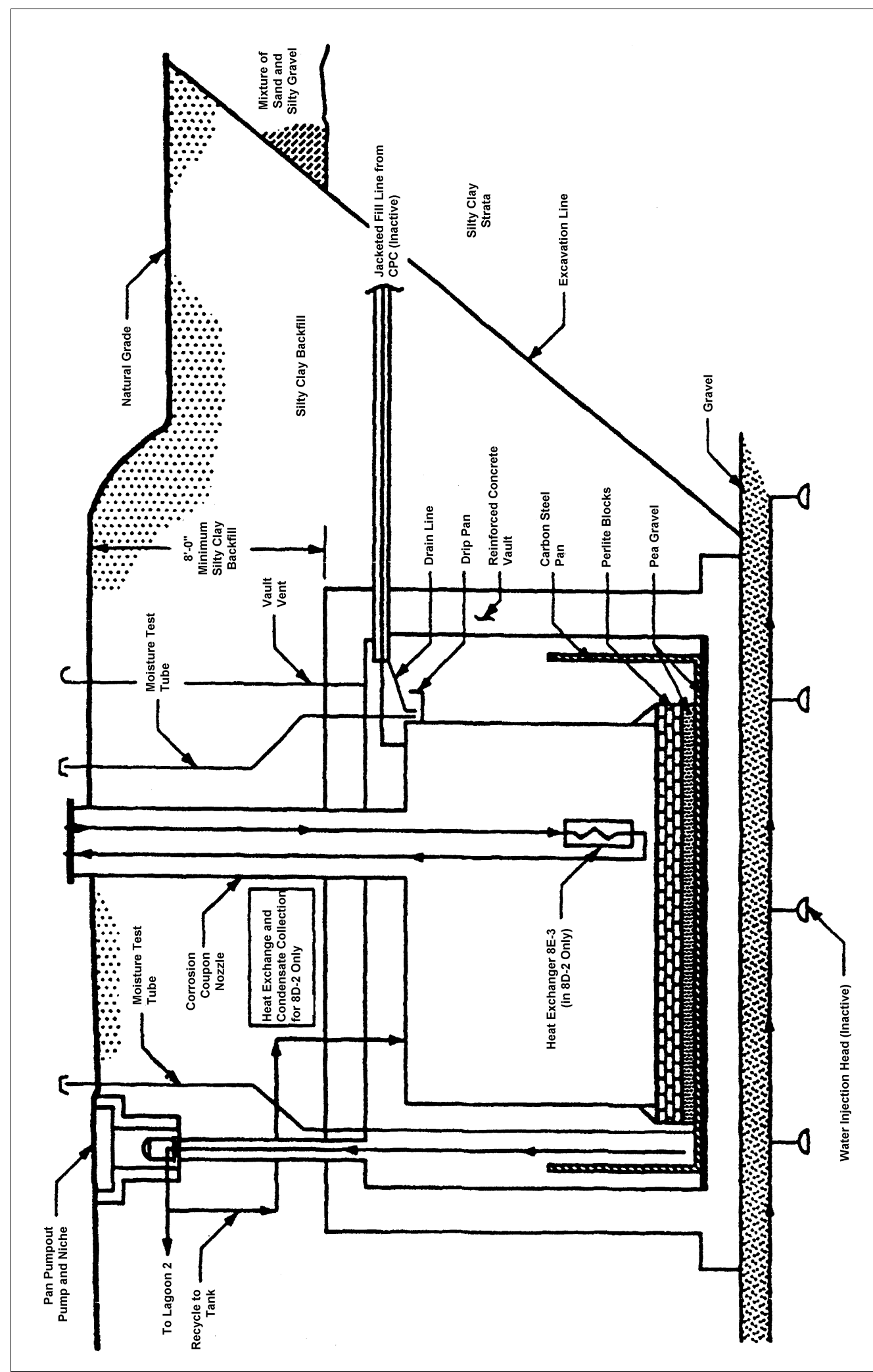

Source: WVDP-141. 
Figure 2. High-Level Waste Storage Tank Interior Structure

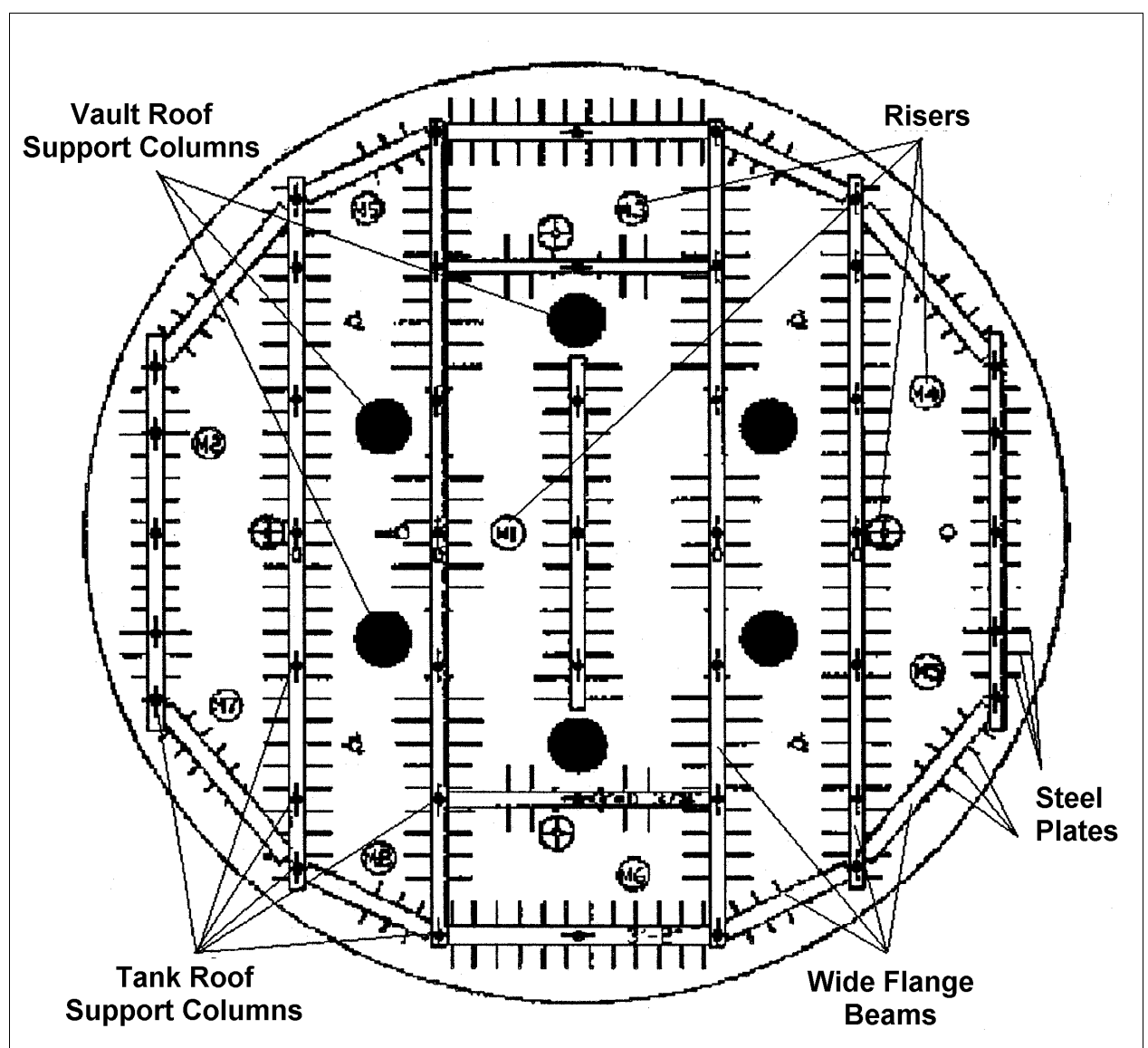

Source: EML-609. 
Figure 3. High-Level Waste Tank Cross-Section with Details of Bottom Gridwork

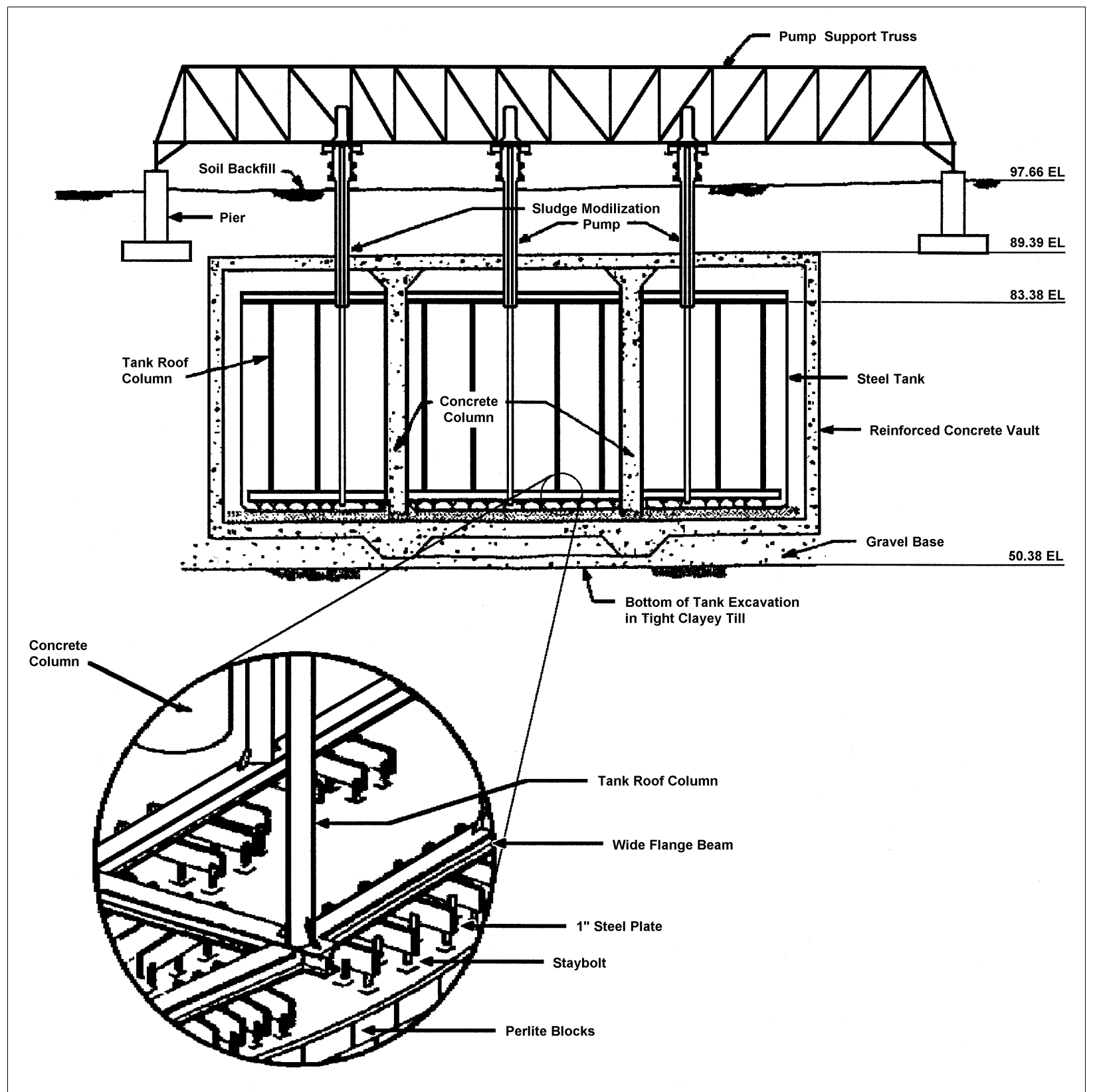

Source: EML-609. 
A 70-m (230-ft) long seismically designed concrete transfer trench connects the tanks to the vitrification facility. Transfer piping within the trench is $6.4-\mathrm{cm}(2.5-\mathrm{in}$.) diameter stainless steel inside a 10-cm (4-in.) diameter stainless steel secondary containment pipe. The trench is equipped with leak detectors, radiation probe penetrations, high-point vents, and exterior valving for monitoring and safety control functions.

A dewatering well between the tanks is used for periodic pumping of water from outside the vaults. The water outside the vaults is never completely removed. The hydraulic pressure of the water is considered secondary containment for any potential leaks into the vault. No records are currently kept on the volume of groundwater pumped. Liquid can also be pumped from the secondary containment pans (see Figure 1). Water is currently pumped from outside the vaults on a weekly basis and pumping from the containment pans is necessary only one to four times per year. There is currently very little ingress of water into the vaults, but the humidity is always at or near $100 \%$.

There has been no leakage of waste from the tanks. However, very small amounts of contamination have been detected in water pumped from inside the tank $8 \mathrm{D}-2$ vault.

The contamination is believed to be from small leaks during transfers of waste from the process building that were washed into the vault by water percolation from the surface. This conclusion is supported by the discovery of contaminated soil when new penetrations were added to the vault and tank (Fussner 2001).

\subsection{WASTE PRETREATMENT}

Pretreatment to remove chemical compounds (e.g., sodium sulfate) that have a detrimental effect on the final vitrified HLW form began in 1988. The supernate in HLW tank 8D-2 was processed using ion-exchange columns containing zeolite located inside spare HLW tank 8D-1.

Ion exchange removed greater than $99.9 \%$ of the radioactive materials (mostly cesium-137). The resultant effluent salt solution was concentrated and blended with cement and is stored as low-level waste in a shielded, aboveground, onsite facility. Supernate processing was completed in 1990 producing slightly over 10,000 drums.

Without pretreatment of the HLW the quantity of vitrified waste would have been about 10 times the current estimated projection of 300 glass-filled canisters. The remaining waste (mostly solids from tank sludge and zeolite ion-exchange media) was mobilized by mixing pumps and transferred to the vitrification facility for solidification into glass logs.

\subsection{HIGH-LEVEL WASTE MOBILIZATION AND TRANSFER}

Mobilization pumps were installed mix and wash the sludge portion of the waste. This washing process included the addition of water to the tank to dissolve additional interstitial sulfates. Salt/sulfate removal was necessary to reduce the amount of these compounds processed into glass and the resulting quantity of canisters produced during the vitrification campaign. The wash water was then processed similarly to the supernate; however, titanium-coated zeolite was used in the ion-exchange columns. The titanium-coated zeolite adequately captured cesium-137 and also captured plutonium and strontium that had dissolved during the washing process. Sludge washing created 2,900,000 1 (765,000 gal) of liquid that was processed as 
supernate liquids, then evaporated, mixed with cement, and placed in 8,033 265-L (70-gal) steel drums.

During 1995 the acidic THOREX waste $(85,000 \mathrm{~kg}$ or 94 tons, containing 40\% water and 50\% nitrates of thorium, iron, and aluminum) in tank 8D-4, leftover from past fuel reprocessing, was combined with the waste in tank 8D-2 and chemically neutralized. The resulting THOREX sludges and the PUREX sludge were then washed and processed. The net effect of the wash was an additional 1,100,000 L (300,000 gal) of liquid waste solidified into 1,451 drums.

The processing of liquid from washing the PUREX-based sludge and the additional THOREX waste was completed in 1995, resulting in a total of 6,400,000 L (1,700,000 gal) of liquid being processed and a total of 19,877 drums of cement-based waste produced and stored onsite.

The spent zeolite from the ion-exchange process in tank 8D-1 was then transferred to tank 8D-2. The zeolite particles were size-reduced with an in-line grinder during transfer operations.

The remaining zeolite and sludge mixture is the feed for the vitrification process providing $17 \%$ of the glass chemical composition. The waste consists of insoluble metal hydroxides with ferric hydroxide being the major constituent. The sludge mass was estimated at 100,000 kg $(220,000 \mathrm{lb})$ with a specific gravity of 3.35 . Based on sludge sampling and analysis, the particle size of the sludge was generally less than 100 microns. The predominant radionuclides in the sludge are strontium-90 and isotopes of thorium and uranium.

From June 1996 through September 1998 over 102 transfers of waste from tank 8D-2 to the vitrification facility were completed. These transfers made up 58 batches of feed for the melter containing 10,300,000 curies of cesium-137 and strontium-90, and comprised approximately $88 \%$ of the initial HLW tank inventory. Other liquids from laboratory analysis of samples, distillates from waste concentration in the vitrification facility, and clean water used to lubricate and cool the mobilization pump driveline bearings were added to tank 8D-2 during this period. Volume reduction of some of the excess liquid was performed in the Integrated Radwaste Treatment System. Some portion of the liquid was decanted back to tank 8D-1. Both operations were critical to maintaining the HLW concentration in the primary waste tank supplying the vitrification facility.

From October 1, 1998 to December 31, 1999, 24 transfers of waste from tank 8D-2 to the vitrification facility were completed. These transfers made up 3 feed batches and contained approximately 460,000 curies of cesium-137 and 160,000 curies of strontium-90 for a total of 620,000 curies.

As of March 2001 the total contents of tank 8D-1 and tank 8D-2 are estimated to be approximately 2,300,000 L (600,000 gal) of liquid waste with about 19,300 kg (42,500 lb) of dissolved chemical species consisting primarily of sodium nitrate, sodium nitrite, sodium carbonate and sodium formate. This liquid also contains about 30,000 curies of radioactive species, primarily cesium-137 and small quantities of hazardous chemical constituents such as chromium and mercury. In addition to the liquid and residual solids in the bottom of the tanks, there is a "bathtub ring" of dried solids on the walls and internal structures of tank $8 \mathrm{D}-2$ (Wallon 2001). 
Most of this liquid will be removed from the tanks and additional cleaning of the internal surfaces will be completed prior to lay-up. The residual waste will then be characterized. Options for final treatment of the current inventory of sodium waste are being evaluated. Methods for removal of the 'bathtub ring' are also being evaluated.

\subsection{HYDROLOGY OF SITE}

The WVDP facilities are located within a U-shaped bedrock valley filled with approximately $150 \mathrm{~m} \mathrm{(500} \mathrm{ft)} \mathrm{of} \mathrm{Pleistocene} \mathrm{glacial} \mathrm{deposits} \mathrm{that} \mathrm{form} \mathrm{a} \mathrm{till} \mathrm{plain.} \mathrm{A} \mathrm{cross-sectional} \mathrm{view} \mathrm{of} \mathrm{the}$ deposits within the valley is shown in Figure 4. There is a sand and gravel layer above a layer of unweathered lavery till. The unsaturated zone is within the sand and gravel layer that has a

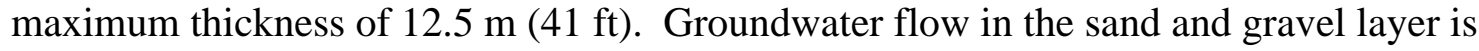
predominantly to the east-northeast toward Franks Creek and Erdman Brook. Figure 5 provides additional detail of the geological cross-section in the area of the WVNS facilities and tank farm.

Recharge of the groundwater system within the bedrock valley is primarily from precipitation within the watershed and not from subsurface flow from regional drainages. The water table in the area of the facilities varied between 0.3 to $1.5 \mathrm{~m}$ ( 1 to $5 \mathrm{ft}$ ) below the surface from 1990 to 1992. From 1981 to 1992 the depth to groundwater ranged from 1.2 to $3 \mathrm{~m}$ ( 4 to $10 \mathrm{ft}$ ). Water levels are typically higher in fall through spring and lower during the summer.

The average annual recharge has been estimated at $40 \%$ of the annual precipitation with $60 \%$ lost to runoff. A geological survey in 1987 estimated that springs and seeps account for $36 \%$ of the total annual discharge from the sand and gravel layer while evapotranspiration to the surface accounts for $30 \%$ and drainage to streams accounts for $19 \%$. Vertical downward flow to the lavery till was estimated at only $1 \%$. Figure 6 shows the hyrologic cycle for the site.

The WVNS site is on the western edge of the bedrock valley.

\subsection{STATUS OF THE WEST VALLEY DEMONSTRATION PROJECT ENVIRONMENTAL IMPACT STATEMENT}

DOE is planning to separate the environmental impact statement (EIS) for completion of closure of the WVDP into two separate EISs. The first EIS will cover only waste management and decontamination. DOE expects to complete this EIS in about 18 months. The second EIS will cover final decommissioning and may take up to five years to complete. This approach has been proposed to expedite continued management of the waste and decontamination activities in advance of the final EIS and Record of Decision on final site closure. DOE believes the two-EIS approach fulfills the requirements of the "1987 Stipulation of Compromise with the Coalition on West Valley Nuclear Wastes" (WVNW 1987), requirements under the WVDPA and National Environmental Policy Act of 1969 requirements. Final closure of the WVDP site may take 10 to 15 years. 
Figure 4. Cross-Section of the Buried Bedrock Valley

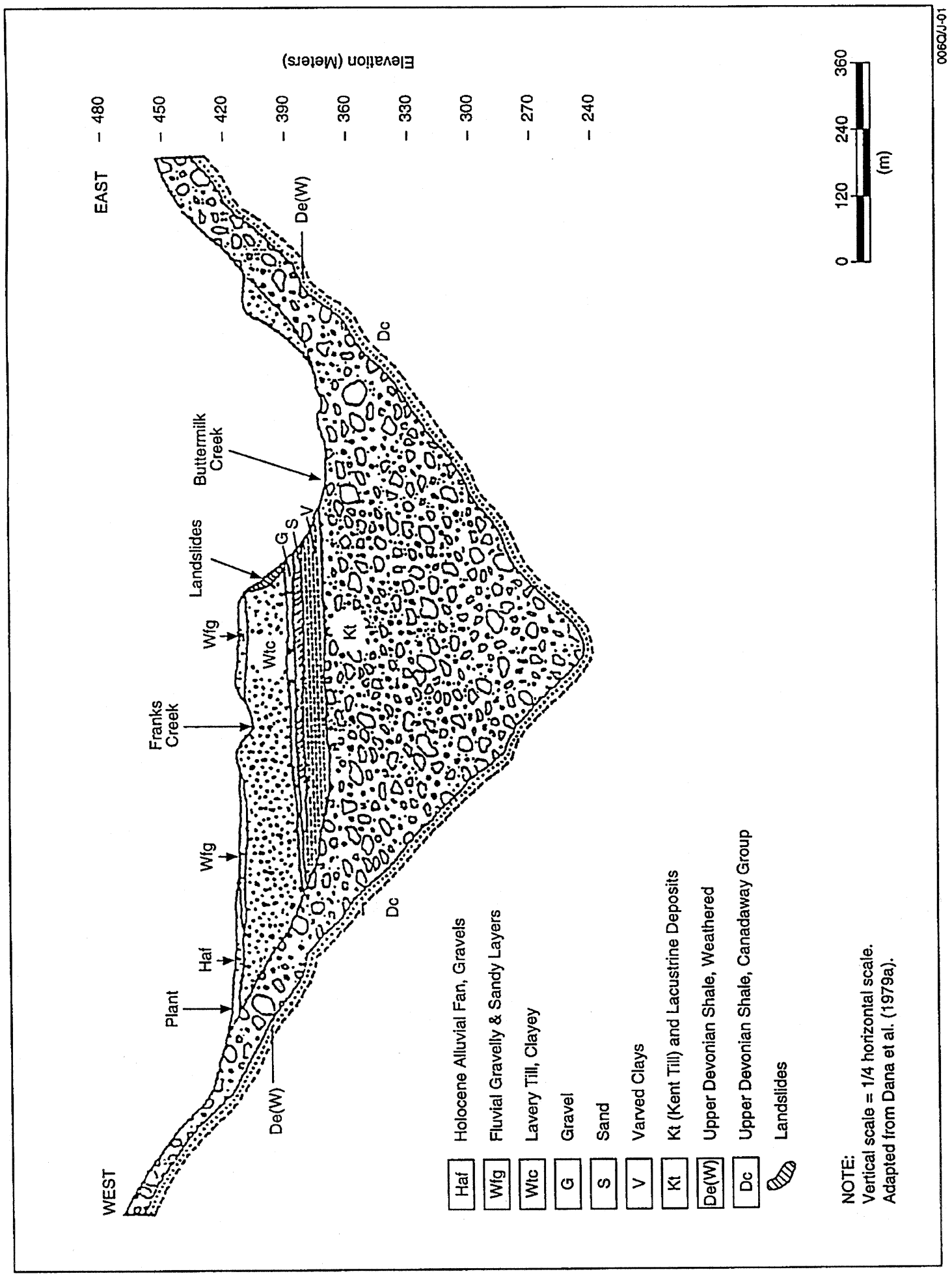

Source: DOE/EIS-0226-D. 
Figure 5. Geologic Cross-Section through the North Plateau

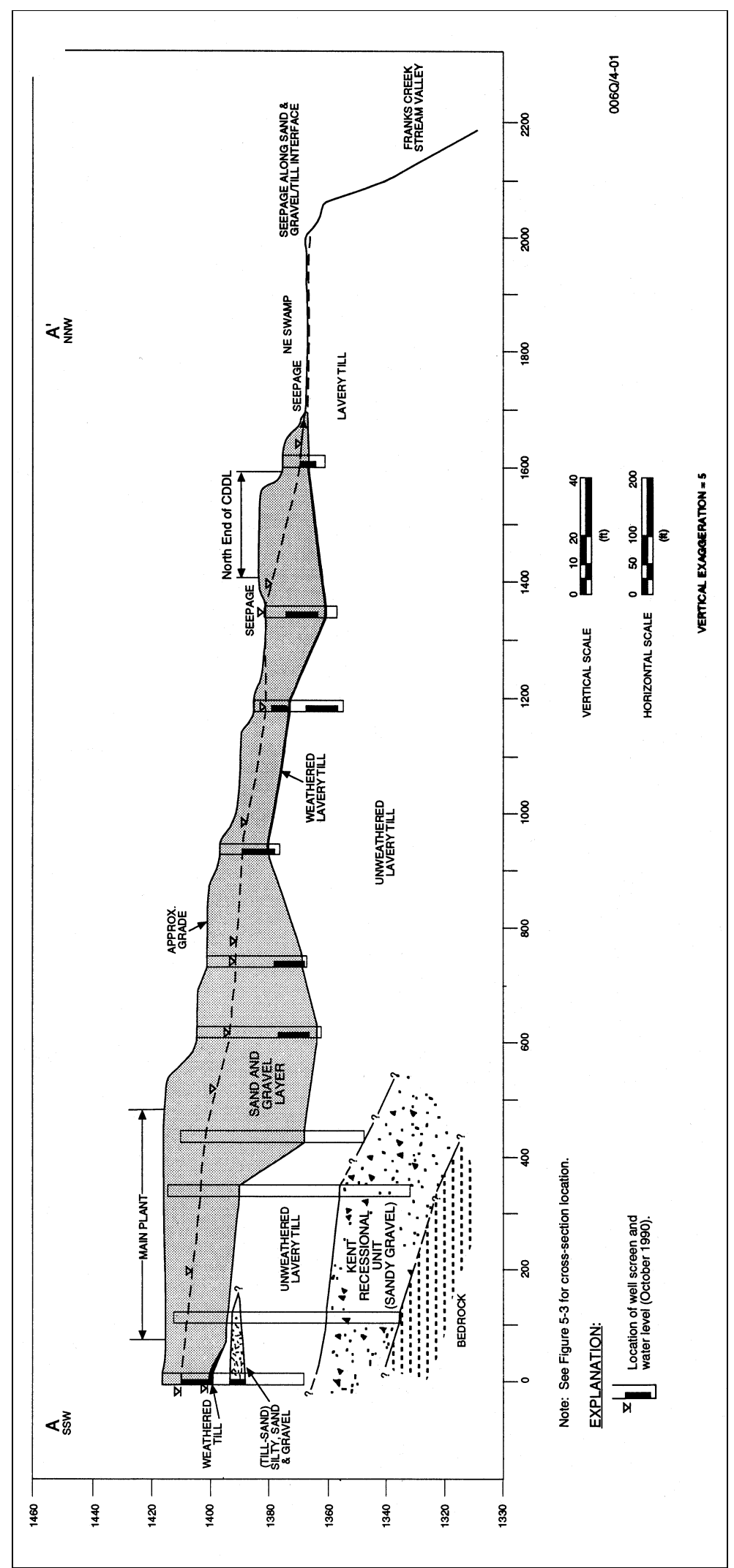

Source: DOE/EIS-0226-D. 
Figure 6. Idealized Cross-Section Showing Hydrologic Cycle, Distribution of Saturated and Unsaturated Zones, and General Directions of Water Movement

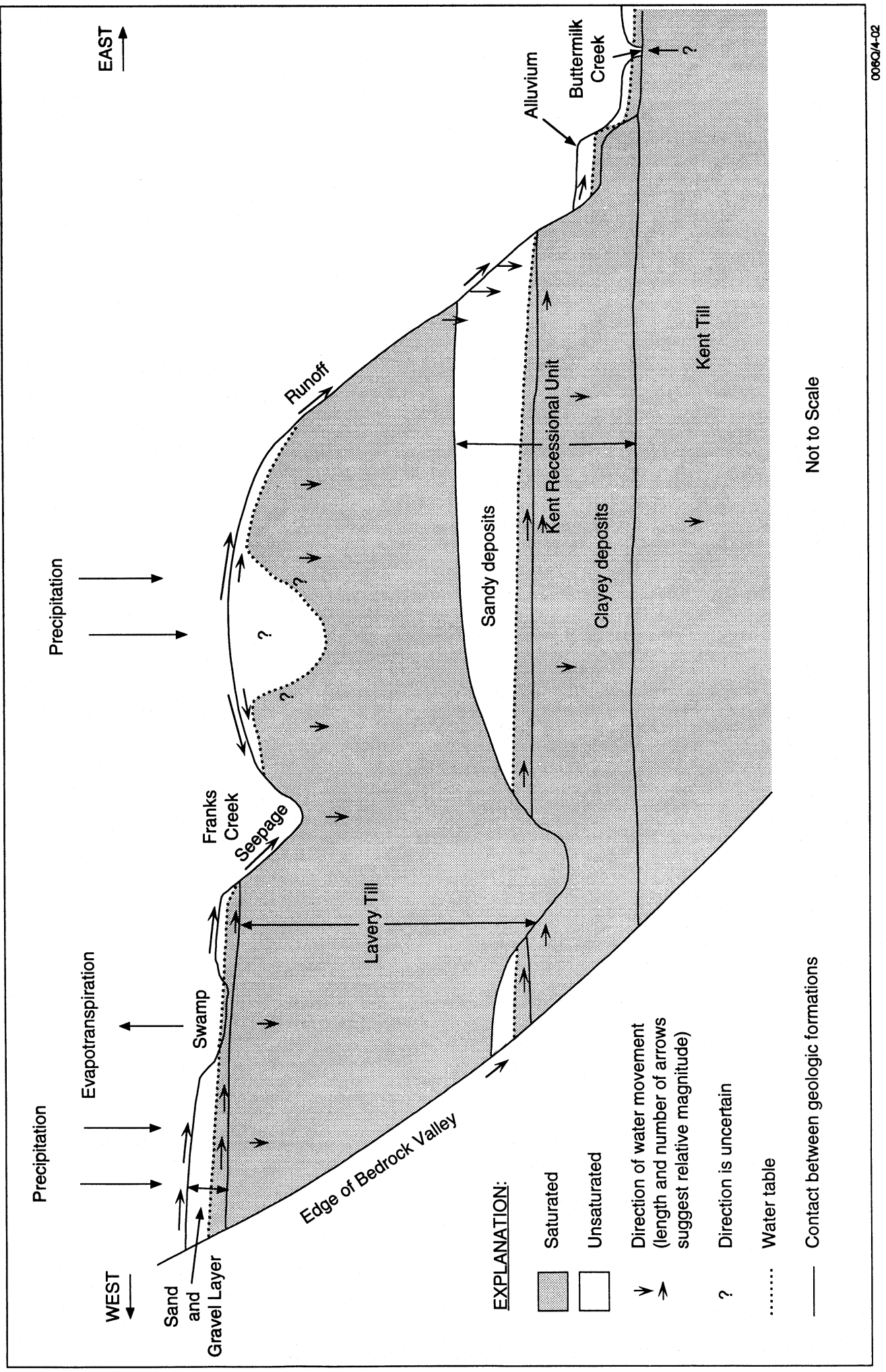

Source: DOE/EIS-0226-D. 


\subsection{FUNCTIONS AND REQUIREMENTS FOR TANK LAY-UP}

The primary function of the tank and auxiliary systems is to contain the waste and prevent releases to the environment. The primary objective for temporary tank lay-up is to put the tank into a safe and stable configuration with minimum capital and operating costs for up to a 20-year period of time. The requirements for the tank system to continue to perform this function during the lay-up period are primarily subjective. It is not possible to construct specific, objective functional requirements. Therefore, the requirements listed below will serve as the evaluation criteria for identifying the preferred option. Some of the requirements identified below are firm requirements (e.g., safety) while others are more value based. Weighting factors will be developed as part of the decision plan to provide a means for ranking alternative lay-up strategies. The weighting factors can be used as a way to vary the importance or influence of the different requirements on the evaluation of lay-up strategies.

- Comply with regulations and permit requirements - All regulations and permit requirements must be complied with during the lay-up period. Effluent releases must be maintained within permitted limits. This will require maintaining gaseous and liquid treatment capabilities for tank ventilation and potential treatment of liquids pumped from inside or around the vaults.

- Prevent release of tank contents to the groundwater - There shall be no release of any amount of the tank contents to the groundwater. This is a consideration during any preparatory activities and during the lay-up period.

- Ensure acceptable risk to workers and the public - The risks associated with the installation of any new equipment required for the selected option must be as low as reasonably achievable. However, the selected option should result in a reduced risk to workers and the public during the lay-up period.

- Maintain integrity of the tanks - The ability of the tanks to continue to contain the waste residual must be maintained. Further corrosion of the tanks must be controlled, and the structural integrity of the tanks must be ensured.

- Establish a safe operating envelope during temporary lay-up - The operational requirements during the lay-up period must continue to be within safe limits, but reduced monitoring and surveillance should be considered in evaluating options.

- Control construction and operating costs - The cost of installing new equipment and the continued operating costs are considerations for selecting a preferred option. Construction and operating costs must be within projected budgets.

- Utilize accepted methods and technologies - The preferred option should be based on proven construction methods and demonstrated technologies.

- Avoid production of secondary wastes during construction and operation - Options that may produce secondary wastes, especially radioactive wastes that will require further treatment and disposal, should be avoided. 
- Preserve future options for decontamination and final closure - The selected lay-up option must maintain the ability to sample the waste, perform additional waste removal, and complete additional decontamination of the tanks if necessary. Also, the lay-up option selected must not preclude either of the currently identified final closure options of in-place stabilization and complete removal.

- Gain acceptance for lay-up - The selected option must be acceptable to stakeholders. Any changes to permits or other requirements must be acceptable to regulatory agencies.

- Reduce monitoring and surveillance - Reductions in monitoring and surveillance, consistent with requirements, is desired.

\subsection{REFERENCES}

DOE/EIS-0226-D, 1996, Draft Environmental Impact Statement for Completion of the West Valley Demonstration Project and Closure of Long-Term Management of Facilities at the Western New York Nuclear Service Center, U.S. Department of Energy, New York State Energy Research and Development Authority, New York.

EML-609, 2000, West Valley Demonstration Project Waste Management Area \#3 - Closure Alternative I, West Valley Nuclear Services Company, Inc., West Valley, New York.

Fussner, R. J., 2001, communication record of personal communication with Robert J. Fussner, West Valley Nuclear Services Company, Inc., West Valley, New York.

National Environmental Policy Act of 1969, 42 USC 4321 et seq.

Wallon, D. V., 2001, communication record of personal communication with Doug V. Wallon, West Valley Nuclear Services Company, Inc., West Valley, New York.

WVDP-141, 1992, Resource Conservation and Recovery Act Closure Plan for the High Level Waste Process Tanks: Tanks $8 D-1$ \& 2, West Valley Nuclear Services Company, Inc., West Valley, New York.

West Valley Demonstration Project Act, 42 USC 2021a, et seq.

WVNW, 1987, Stipulation of Compromise with the Coalition on West Valley Nuclear Wastes, U.S. District Court, Western District of New York. 